\title{
DEPOCEN
}

Working Paper Series No. 2007/02

\section{Testing for Structural Breaks and Dynamic Changes in Emerging Market Volatility}

\author{
Duc Khuong Nguyen * \\ Mondher Bellalah **
}

* Professor of Finance, ISC Paris School of Management 22 Boulevard du Fort de Vaux, 75848 Paris cedex 17, France

** University of Cergy-Pontoise

The DEPOCEN WORKING PAPER SERIES disseminates research findings and promotes scholar exchanges in all branches of economic studies, with a special emphasis on Vietnam. The views and interpretations expressed in the paper are those of the author(s) and do not necessarily represent the views and policies of the DEPOCEN or its Management Board. The DEPOCEN does not guarantee the accuracy of findings, interpretations, and data associated with the paper, and accepts no responsibility whatsoever for any consequences of their use. The author(s) remains the copyright owner.

DEPOCEN WORKING PAPERS are available online at http://www.depocenwp.org 


\title{
Testing for Structural Breaks and Dynamic Changes in Emerging Market Volatility
}

\author{
Duc Khuong Nguyen ${ }^{\mathrm{a}, *}$, Mondher Bellalah ${ }^{\mathrm{b}}$ \\ ${ }^{a}$ ISC Paris School of Management, dnguyen@groupeisc.com \\ ${ }^{b}$ University of Cergy-Pontoise
}

\begin{abstract}
This paper aims to test for structural breaks and dynamic changes in emerging market volatility. We typically relate these issues to stock market liberalization since the latter is often considered as one of the most important forces that promote economic growth and rapid maturation of the emerging markets of the world. Using a bivariate GARCH-M model, stability tests in a linear framework and a pooled time-series cross-section model, we show that structural breaks detected in emerging market volatility series do not happen together with official liberalization dates, but they rather coincide with dates of the first ADR/Country Fund introduction and with dates of large increases in the US capital flows. Consistently, the pooled estimation results indicate that liberalization methods other than liberalization via a formal policy decree are the ones that significantly affect volatility.
\end{abstract}

Keywords: Stock Market Liberalization, Return Volatility, Emerging Markets, Bivariate GARCH-M models, Structural Breaks, Pooled Time-Series Analysis.

JEL Classification: F3, G15

\footnotetext{
* We would like to thank the participants of the 2005 Annual Meetings of the European Financial Management Association (Milan, Italy) and the $5^{\text {th }}$ INFINITI Conference on International Finance for helpful comments (Dublin, Ireland). Corresponding author: D.K Nguyen, Professor of Finance, ISC Paris School of Management, 22 Boulevard du Fort de Vaux, 75848 Paris Cedex 17, France.
} 


\section{INTRODUCTION}

In the late 1980s, many emerging economies had decided to open their capital markets to foreign investors. Within this context, foreign investors are now allowed to trade domestic securities and domestic investors have rights to hold shares issued in foreign markets. This market reform has led to significant changes in stock markets of emerging countries due to the increased foreign portfolio investment. The rapid maturation of institutional infrastructure and the substantial growth of market depth witnessed these changes. In 2004, the relative size of all emerging markets reaches more than $11 \%$ of world market capitalization while it was only $2.5 \%$ in $1982^{1}$. In addition, if we take a close look at the evolution of market-liquidity indicators, it appears that many emerging markets have currently a turnover ratio comparable to the one of mature markets.

Since stock market liberalization is considered as one of the major forces for creating a new environment for financial investments in emerging countries, many studies have empirically examined the changes which occurred in emerging stock markets after the liberalization (see, Bekaert and Harvey, 2003). The majority of these studies report that the liberalization of stock markets was beneficial to emerging countries in that it allows for international risk sharing between domestic and foreign investors through capital market integration (see, e.g., Bekaert and Harvey, 1995; Stulz, 1999; Carrieri and al., 2002; and Iwata and $\mathrm{Wu}, 2004)$. There is also empirical evidence to suggest that the actual liberalization may lower the cost of capital leading to economic welfares (see, e.g., Bekaert and Harvey, 2000; Henry, 2000; and Bekaert and al., 2001). In addition, several studies provide evidence that the liberalization of stock markets improves informational efficiency as foreign investors often require high transparency and appropriate accounting regulations (see, e.g., Kim and Singal, 2000; Khambata, 2000). However, liberalization could be harmful to stock markets in new liberalized countries. Some authors have argued that foreign trading and free capital mobility resulting from liberalization policies may increase stock market volatility and instability leading to market crashes (see, e.g., Calvo and Reinhart, 1996; 
Krugman, 1998; Froot and al., 2001; and Borenzstein and Gelos, 2001). The proponents of this view often refer to the advent of financial turmoil during the 1990s as a good example of adverse effects induced by market liberalization policies.

The above ambiguities about the effect of liberalization policies have recently made stock market liberalization under strong debate, essentially in the aftermath of the sonorous 1997 Asian financial crisis. Therefore, asking seriously a question of whether liberalization leads to increased volatility in emerging stock markets is purely rational and of great interest. Various empirical studies have been done concerning this topic (Bekaert and Harvey, 1997; DeSantis and Imrohoroglu, 1997; Bekaert and Harvey, 2000; Kim and Singal, 2000; Kassimatis, 2002; Miles, 2002; and Jayasuriya, 2005). While the majority of these studies report that stock market liberalization contributes to lower emerging market volatility, there is also the empirical evidence suggesting an intensification of volatility after liberalization.

To start, the proposition that emerging stock markets become less volatile after liberalization is supported by papers such as Bekaert and Harvey (1997, 2000), Kim and Signal (2000), and Kassimatis (2002). Precisely, the purpose of Bekaert and Harvey (1997) is to investigate stock market volatility using monthly data of twenty emerging markets from the International Finance Corporation. They use a semi-parametric $\mathrm{ARCH}(\mathrm{SP}-\mathrm{ARCH})$ model to estimate the volatilities of each market and document that thirteen of seventeen countries that opened their stock markets to foreign capital flows experience a decline in volatility while only four countries exhibit a slight increase in volatility. After controlling the potential influences on conditional volatility of several variables such as asset concentration, stock market development and integration indicators, microstructure effects, and macroeconomic influences and political risk, Bekaert and Harvey (1997) found that stock market liberalization significantly decreases volatility in emerging markets. In a related work, Bekaert and Harvey (2000) extended the time series data used in Bekaert and Harvey (1997) to study the effect of liberalization over a longer period and estimate the volatility of sample markets from a time series model which allows both the conditional mean and condi- 
tional variance to vary through time. The conditioning variables they used essentially reflect changes in the degree of capital market integration between emerging and world markets. These authors then employ their model's estimates in a pooled crosssectional framework to evaluate the effects of liberalization on stock market volatility. Overall, when control variables are taken into account, their adjusted results indicate that, on average, annualized volatility decreases by one basis point. In a related study, Kim and Signal (2000) focused on the volatility changes around market liberalization for fourteen markets from an initial sample of twenty emerging markets. Using various versions of $\mathrm{ARCH} / \mathrm{GARCH}$ models to measure conditional volatilities of each market and an event study methodology, they found that the volatility of emerging markets under consideration is lowered over the post-liberalization period. Kassimatis (2002) also analyzed the effect of liberalization on emerging market volatility and provided evidence that EGARCH-based volatility measures significantly decrease following official liberalization dates in 6 emerging countries.

Other attempts such as Levine and Zervos (1998), and Miles (2002) reported empirical results which are in contrast to those of the aforementioned studies. For example, Levine and Zervos (1998) examined the links between capital control liberalization and volatility in sixteen emerging stock markets and found that conditional volatility as measured by the rolling standard deviation of monthly market returns in most countries tends to grow up when capital controls are removed. In a more recent study, Miles (2002) discussed the effects of stock market openings on return volatility for seventeen emerging markets. He proposed to capture the market-liberalization's effect by creating five market reform variables: the month of official liberalization, the month which is marked by a significant change in the US capital flows into emerging markets, the month of December 1989, the month of the first Country Fund introduction and the month of the first American Depository Receipt (ADR) introduction. According to the author, the month of December 1989 was used because it marked the time when investors in developed countries have rights to pur- 
chase financial securities in emerging countries. After selecting the appropriate $\mathrm{ARCH} / \mathrm{GARCH}$ models of volatility for each market in his study, the author tested the relationship between liberalization measures and stock market volatility. As regard to empirical results, Miles (2002) pointed out that they tend to be countryspecific and do not support the hypothesis of decreased volatility in emerging markets following the reforms. Specifically, in three fifth of sample markets, liberalization events do increase rather than lower stock market volatility.

Another kind of results is provided by DeSantis and Imrohoroglu (1997) who examined the behavior of return volatility around market-liberalization events using a GARCH model in which the conditional variance can change with market liberalization. To do so, they added on the conditional variance equation a dummy variable which is equal to zero before official liberalization date and one afterwards. Using data from five emerging markets, they demonstrated that the impact of liberalization on emerging market volatility is economically insignificant.

Finally, the study of Jayasuriya (2005) can be considered as the first effort to conciliate existing results. It revealed that emerging market volatility can increase, decrease or remain unchanged over the post-liberalization period, and all according to the market's specific characteristics and the quality of financial institutions. For example, the volatility of markets with higher transparency and better regulation decreased after market reforms.

As this brief review demonstrates, the literature is quite heterogeneous in terms of variables, methods applied to the same research question and empirical evidences. Moreover, it is worth notifying that earlier works have two major drawbacks. First, the majority of the previous works have treated emerging markets as perfectly segmented markets due to the use of univariate $\mathrm{ARCH} / \mathrm{GARCH}$ processes to model stock market volatility while these markets are viewed as reasonably integrated with world capital markets after being liberalized. Since emerging markets become dependent upon the world market, a bivariate GARCH model for stock market volatility 
or a world factor model of conditional variances as in Bekaert and Harvey (1997) would be more suitable for the influences of both local and world market information on the return generating process. The second drawback directly refers to the measure of liberalization effects. Effectively, some papers attempted to assess the changes in return volatility by splitting the study period into two sub-samples, which is critical because the volatility of stock markets may react to liberalization policy before the official liberalization dates. In addition, if some papers have merit to consider a variety of market-liberalization reforms (e.g., Miles, 2002), they do not yet take into account control variables and thus, the effects of market liberalization on volatility might be overvalued. From this point of view, the exact role of stock market reforms still remains unclear.

The aim of our paper is to provide further understandings about the dynamic behavior of emerging market volatility under stock market liberalization policies. We also ask the question as to which type of liberalization has had the most significant impact on market volatility. To this end, we begin by modeling emerging market volatility, then test for structural breaks in the estimated conditional volatility using some stability tests, and finally explain the relationship between estimated conditional volatility and stock market liberalization policies across all time periods and markets. Unlike previous studies, however, we employ a bivariate GARCH-M model for stock market volatility instead of univariate GARCH models. By mainly arguing that change in emerging market volatility around stock market liberalization is likely due to unmeasured country specific factors, our pooled time-series cross-sectional regression framework take into account the country heterogeneity with respect to market liberalization policies.

The remainder of this paper is organized as follows. Section 2 describes the data. Section 3 briefly describes the empirical methodology. Section 4 reports and discusses empirical results. Section 5 concludes the paper. 


\section{THE DATA}

The data used in this study are on monthly basis and consist of the S\&P's IFCG total return indices for seven emerging markets and the MSCI World stock market index, sampled over the period January 1985 to January 2003. The emerging market countries included in the study are: Argentina, Brazil, Chile, Colombia, Mexico, Malaysia and Thailand. All the price data were extracted from Datastream International and measured in US dollars. They are converted to return using the log price relative filter. Data employed in constructing liberalization proxy variables and control variables are derived from the $\mathrm{S} \& \mathrm{P}^{\prime}$ s Emerging Market Database (trading value, market capitalization and turnover), the IMF's International Financial Statistics (GDP, imports, exports, interest rates, exchange rates and inflation rates) and the International Country Risk Guide (political stability index).

Descriptive statistics and stochastic properties of monthly returns are not presented here to conserve space. However, we can note similar to previous studies that monthly return series in emerging markets are significantly deviated from the normal distribution based on the results of the Jarque and Bera's (1980) test for normality. In addition, the Engle's (1982) test for conditional heteroscedasticity reject the null hypothesis of no ARCH effects in monthly return series. Finally, the Dickey and Fuller's (1981) augmented stationarity test with four lagged terms rejects the null hypothesis of non-stationary return series. There is then no need for integrated series treatments.

\section{THE ECONOMETRIC METHODOLOGY}

\section{A. Modeling stock market volatility}

On modeling emerging market volatility, existing studies have mostly employed ARCH/GARCH-type models, which are respectively introduced by Engle (1982) and Bollerslev $(1986)^{2}$. The rationale for doing so is that GARCH models appear to suc- 
cessfully describe the stochastic properties of stock price volatility. Accordingly, in this paper we specify a bivariate GARCH-M model to measure stock market volatility in emerging countries. This specification is supported by the idea that emerging market returns are relatively dependent on the changes in world market returns due to increasing integration after liberalization (see, e.g., Bekaert and Harvey, 1995; Carrieri and al., 2003; and Gerard and al., 2003). More importantly, some empirical studies focusing on the international transmission of volatility found significant volatility interactions between emerging and world markets (see, e.g., Liu and Pan, 1997; and He, 2001).

Formally, we model the conditional return on the world stock market index $\left(R_{w, t}\right)$ and that on the stock market index of the emerging country $i\left(R_{i, t}\right)$ by the following bivariate extended $\mathrm{AR}(1)$ process:

$$
\left\{\begin{array}{l}
R_{w, t}=\alpha_{0}+\alpha_{1} R_{w, t-1}+\alpha_{2} h_{w, t}+\varepsilon_{w, t} \\
R_{i, t}=\beta_{0}+\beta_{1} R_{i, t-1}+\beta_{2} R_{w, t-1}+\beta_{3} h_{i, t}+\beta_{4} h_{w i, t}+\varepsilon_{i, t}
\end{array}\right.
$$

where $h_{w, t}$ and $h_{i, t}$ denote the conditional variance of the world and local market returns respectively. $h_{i w, t}$ represents the conditional covariance between the return on emerging market $i$ index and the return on world market index. Then, the parameters $\beta_{3}$ and $\beta_{4}$ can be intuitively viewed as the local and global betas in an asset pricing model. Assume that the innovation process $\varepsilon_{t}=\left(\varepsilon_{w, t}, \varepsilon_{i, t}\right)$ is normally distributed with mean 0 and conditional variance $H_{t}$, the bivariate structure of a symmetric $\operatorname{GARCH}(1,1)$ specification for conditional variance is given as follows:

$$
H_{t}=\left(\begin{array}{cc}
h_{w, t} & h_{w i, t} \\
h_{i w, t} & h_{i, t}
\end{array}\right)=C_{0}^{\prime} C_{0}+A_{1}^{\prime} \varepsilon_{t-1} \varepsilon_{t-1}^{\prime} A_{1}+B_{1}^{\prime} H_{t-1} B_{1}
$$

where $A_{1}$ and $B_{1}$ are $(2 \times 2)$ parameter matrices and $C_{0}$ is an upper triangular matrix. This is the bivariate version of the so-called BEKK multivariate GARCH model which ensures the cross dynamics of conditional covariance (see, Engle and Kroner, 
1993). Under the weak condition that at least one of the matrices $C_{0}$ or $B_{1}$ has the full rank, $H_{t}$ is positively definite because the right-hand side of (2) contains only quadratic terms.

Under these specifications, our empirical model allows for the influences of the world market on the emerging country $i$ volatility through multiple sources such as the lagged unexpected return, the lagged volatility as well as the conditional covariance between emerging and world market returns.

We estimate the conditional volatility of emerging markets using a two-stage procedure. First, the world market volatility is estimated using a standard univariate GARCH(1,1)-M model. Second, we generate the conditional volatility for each emerging market from estimating our bivariate model in which estimated coefficients from the first stage are held constant to allow the influences of world market to be identical across emerging markets. All models are estimated by Quasi-Maximum Likelihood discussed in Bollerslev and Wooldridge (1992), which corrects for non Gaussian errors.

\section{B. Detecting structural breaks in volatility series}

Since stock market liberalization is one of the most important economic reforms in emerging countries over the last three decades, intuitions can suggest that structural breaks may be present in the time-paths of conditional volatility indices when market reform took place. In this paper two different stability tests are used to test for structural breaks in conditional volatility series of emerging markets: the classical CUSUM test and the Bai-Perron's test (see, Brown and al., 1975; Kramer and al., 1988; Hansen, 1992; Andrews and Ploberger, 1994; Bai, 1997; and Bai and Perron, 1998, 2003 for further discussions).

Consider the following standard linear regression model:

$$
y_{t}=\beta x_{t}^{\mathrm{T}}+\varepsilon_{t} \quad(t=1, \ldots, n)
$$


where $y_{t}$ is the estimated conditional volatility series of an emerging market at the time $t, x_{t}=\left(1, y_{t-1}\right)^{\mathrm{T}}$ is the $(2 \times 1)$ vector of observations of the independent variables with the first component equal to unity, $\beta$ is the $(2 \times 1)$ vector of regression coefficients, and $\varepsilon_{t}$ is $\operatorname{iid}\left(0, \sigma^{2}\right)$. Recall that structural stability tests are concerned with testing the null hypothesis of 'no structural break' against the alternative that the regression coefficients vary over time. Then, if there are $m$ breakpoints under the alternative hypothesis, the overall sample is split into $(m+1)$ segments with constant regression coefficients. Accordingly, the model (3) can be rewritten as:

$$
\begin{aligned}
& y_{t}=x_{t}^{\mathrm{T}} \beta_{1}+u_{t} \quad\left(t=1, \ldots, n_{1}\right) \\
& y_{t}=x_{t}^{\mathrm{T}} \beta_{2}+u_{t} \quad\left(t=n_{1}+1, \ldots, n_{2}\right) \\
& y_{t}=x_{t}^{\mathrm{T}} \beta_{m}+u_{t} \quad\left(t=n_{m}+1, \ldots, n\right)
\end{aligned}
$$

where $n_{k}=\left(n_{1}, \ldots, n_{m}\right)$ contains the $m$ breakpoints and $m$ is treated as unknown.

From this theoretical framework, the classical CUSUM test, initially proposed by Brown and al. (1975), can be implemented by defining the time-varying CUSUM quantity as follows:

$$
W n(t)=\frac{1}{\tilde{\sigma} \sqrt{n-k}} \sum_{j=k+1}^{[k+t(n-k)]} u_{j} \quad[0 \leq t \leq 1]
$$

where $\tilde{\sigma}=\sqrt{\frac{1}{n-k} \sum_{t=k+1}^{n}\left(u_{t}-u\right)^{2}}, u_{j}$ is the estimated recursive residuals from equation (3) and $k$ is the number of regressors. $t$ changes slightly and it is standardized to the interval [0,1]. If there is a single structural break at fixed time $t_{0} \prec 1$, the mean of the recursive residuals will be always equal to zero up to $t_{0}$ and different afterwards. Hence, the CUSUM path will leave its zero mean at $t_{0}$. In practice, the null hypothesis of stability is rejected whenever the path of the CUSUM quantity crosses the critical boundaries estimated using a 95\% level of confidence under the null. It is im- 
portant to note that dating a structural break with the CUSUM test is difficult despite its simple implementation.

Bai and Perron $(1998,2003)$ propose an OLS procedure to determine both the number and location of breaks in the coefficients of linear regression models. Suppose there are $m$ breaks $\left(n_{1}, \ldots, n_{m}\right)$ in the time-path of the dependant variable, the problem of dating structural breaks turns to find the breakpoints $\left(\tilde{n}_{1}, \ldots, \tilde{n}_{m}\right)$ that minimize the objective function:

$$
\left(\tilde{n}_{1}, \ldots, \tilde{n}_{m}\right)=\arg \min _{\left(n_{1}, \ldots, n_{m}\right)} R S S_{n}\left(n_{1}, \ldots, n_{m}\right)
$$

In this formula, $R S S_{n}$ is the resulting residual sum of squares based on the $m$ regressions as shown by equation (4). The breakpoint selection procedure is based on the Bayesian Information Criteria (BIC). When using the Bai-Perron's test to detect the number of breaks and their locations for stock market volatility indices, we first set

the maximum number of breaks to be 5 . If the effective number of breaks is equal to 5 , a higher number of breaks will be chosen so that the testing procedure captures all possible breakpoints.

\section{Testing for the volatility-liberalization relationship}

To assess the effect of stock market liberalization policies on the conditional volatility of emerging markets, our methodological approach is to use a pooled time-series analysis. This technique is useful in that it allows us to incorporate both crosssectional effects of the independent variables on conditional volatility as well as the time-series effect within markets. Formally, the following pooled time-series model with fixed effects will be estimated:

$$
Y_{i t}=\alpha_{i}+\beta X_{i t}^{\prime}+\varepsilon_{i t}
$$

where $Y_{i t}$ represents the conditional volatility series for market $i$ at time $t . X_{i t}^{\prime}$ is the vector of independent variables which includes a one-period lagged conditional volatility $\left(Y_{i t-1}\right)$, four dummy variables, three information variables and four control 
variables $^{3}$. The presence of $Y_{i t-1}$ in the right-hand side of equation (5) aims to control for the fact that the conditional volatility series estimated via the bivariate GARCHM model contains the generated regressor problem. Dummy variables capture the official date of liberalization (OPENING), the date of the first American Depository Receipt introduction (ADR), the date of the first Country Fund introduction (CF), and the date of the structural break in the US capital flows to the emerging markets (USCF). Information variables includes: market size measured by the ratio of market capitalization to GDP (MCAP/GDP), market liquidity measured by the ratio of trading value to market capitalization (TURNOVER), and economic integration degree measured by the total of imports plus exports as a proportion of GDP (TRADE/GDP). The set of four control variables refers to the growth rate of real exchange rate, inflation rate, interest rate, and political stability index. $\alpha_{i}$ are assumed to be fixed parameters which may be correlated with independent variables and intended to explain the within-country variation. The estimation of such a model is carried out using pooled OLS method which corrects for both cross-sectional heteroscedasticity and correlation.

\section{EMPIRICAL RESULTS}

\section{A. Volatility estimates}

Conditional volatility of each emerging market is obtained by estimating the bivariate GARCH-M model (cf. equations 1 and 2). Table 1 reports the estimated coefficients of the bivariate conditional mean specification and summarizes the results from the diagnostics of the model standardized residuals.

\section{[INSERT TABLE 1 HERE]}

At first sight, we observe that most of the coefficients representing the sensitivities to the local and world market risk are insignificant. The conditional covariance has significant impacts on stock market returns in only one country (Brazil), however the 
interpretation of the result is straightforward because the world market risk negatively impacts local market returns. This market condition might force global investors in emerging markets to favor bond investments. There is also evidence of positive and significant relation between local market risk and stock market returns in Brazil. Regarding the diagnostics of standardized residuals, the results from the Engle (1982)'s test shows the absence of ARCH effects which typically indicate that the bivariate GARCH-M model appropriately captures the dynamic variations in emerging market returns.

\section{[ INSERT FIGURE 1 HERE]}

\section{[ INSERT FIGURE 2 HERE]}

Figures 1 and 2 depict the time-varying patterns of conditional volatility indices for two market groups over the study period: Latin American and Asian markets. It is observed that the evolution of emerging market volatility witnesses some periods of extreme movements during the period 1985-2003: in the early 1990s for Latin American markets and in the late 1990s for Asian markets. Concretely, all markets responded largely to the stock market crash happened in October 1987. The advent of the Asian crisis equally generated a notable increase of conditional volatility in Thailand and Malaysia. If we look closely to several periods of high volatility, it is easy to show that large changes in emerging market volatility are often associated with major economic and political events. Consider for example the case of Argentinean stock market. The latter appeared to be greatly volatile just before its official liberalization. The same behavior is found in the Colombian stock market when the government announced that it would allow the peso to devaluate at a faster rate in September, $2^{\text {nd }} 1998$.

\section{B. Structural changes in emerging market volatility}

Figure 3 presents the results of the Brown and al.'s (1975) CUSUM test applied to our estimated market volatility indices. It is observed that, except for Malaysia, the 
null hypothesis of stability is rejected in seven markets since the CUSUM trajectories crossed the $95 \%$ confidence intervals at least one time over the study period. As stated earlier, this only informs us the existence of structural breaks in the time series under consideration, but not the exact number and timing of their occurrence.

\section{[ INSERT FIGURES 3 AND 4 HERE]}

We now apply the Bai and Perron's (2003) testing procedure to detect and date the structural breakpoints in our conditional volatility indices. In principle, a model's optimal number of breakpoints $(m)$ is the one associated with the minimum BIC. For illustration, Figure 4 depicts the BIC for models with $m$ breakpoints for our sample markets. The selected optimal breakpoints for each market are then reported in Table 2. The obtained results are globally consistent with the previous test, except for Malaysia. In fact, the Bai-Perron's test detects two breakpoints for the Malaysia's data while the CUSUM test provides evidence against the structural breaks. In order to check whether this difference emerges from the inclusion of the first lagged regressor in the CUSUM test, we exclude the latter and perform again the CUSUM test. However, the result remains unchanged. In this case, we cannot provide a clear conclusion about the stability of the Malaysia's volatility index.

\section{[ INSERT TABLES 2 AND 3 HERE]}

Table 2 also provides the estimated break dates and their 95\% confidence intervals. If we compare these dates to the liberalization dates in Table 3, we find that the official liberalization dates fall into the $95 \%$ confidence intervals for the estimated break date in only two markets, Argentina and Chile. A straightforward intuition is that the official liberalization dates will have less explanatory power about the changes in return volatility. Using a GARCH methodology with structural breaks, Aggarwal and al. (1999) made the same conclusion. As regards other markets, the results indicate that the date of structural change in the US capital flows into Brazilian market is located within the $95 \%$ confidence interval of the first break date. In Colombia, 
the dates where the first ADR and Country Fund are introduced, and the date where there is structural change in the US capital flows into this emerging market are bounded by the $95 \%$ confidence interval of the first break date. The same pattern is found in Mexico for the dates of the first Country Fund and ADR introduction. In Malaysia and Thailand, none of the estimated break dates is related to marketliberalization events. However, the break date observed in Thailand can be attributed to the 1997 Asian financial crisis.

To summarize, our stability tests showed that structural changes do not appear at the time of official liberalization, but rather occur when financial instruments like Country Fund and ADR related to an emerging market are firstly launched and also when the US capital flows into emerging markets increase largely. This may indicate that emerging market volatility responds less to the official liberalization than to its subsequent events. In the next section, we will proof this empirical relation based on a pooled time-series regression analysis.

\section{The impact of liberalization on emerging market volatility}

The results from the estimation of the model in Equation (5) are reported in Table 4. Specifically, in the first regression we only use a one-period lagged conditional volatility $\left(Y_{i t-1}\right)$ and market-liberalization's dummies as explanatory variables. On average, the results show that conditional volatility is lowered at the $10 \%$ level of significance following a considerable amount of US capital flows into emerging markets (cf., USCF variable). Other market-liberalization's dummies do not affect significantly market volatility. The high level of significance of $Y_{i t-1}$ confirms again the generated regressor problem when the estimated conditional volatility is used as dependent variable in the pooled time-series model.

\section{[ INSERT TABLE 4 HERE]}

The results of the second regression in which we use both market-liberalization's dummies and information variables as explanatory variables are interesting. The 
USCF variable continues to significantly reduce stock market volatility at the conventional levels of significance. With regard to the information variables, the results demonstrate that a greater degree of economic integration measured by TRADE/GDP ratio and an increase in the TURNOVER ratio significantly emphasize stock market volatility. This is understandable because the presence of foreign participants and the high volume of trades are often considered as sources of stock volatility. More importantly, the relative size of stock market to GDP, measured by MCAP/GDP ratio (cf., indicator of market development), contributes to diminish stock market volatility at $1 \%$ level of significance.

The results of the third regression where control variables are introduced are not much different from the second regression. As before, stock market volatility decreases when emerging markets become more mature and open to foreign portfolio investments. The impact of turnover ratio and trade to GDP ratio on stock market volatility is still positive and significant. Finally, among control variables, we find a significant and positive relation between changes in exchange rate and stock market volatility. Changes in inflation rate and interest rate negatively and significantly influence emerging market volatility. However, the growth rate of the political stability index has no impact on volatility.

Overall, our results based on the pooled time-series analysis are in line with the empirical prediction provided by structural stability tests in the sense that emerging market volatility is significantly lowered as a follow-up to a sharp increase of the US capital flows. They are also consistent with empirical findings of Bekaert and Harvey (1997), DeSantis and Imrohoroglu (1997), and Bekaert and Harvey (2000), but contrast with recent findings of Miles (2002).

\section{CONCLUSION}

Measuring volatility is of paramount importance in the literature of financial economics and econometrics. For example, portfolio managers can evaluate and hedge 
against risk or price derivatives based on volatility measures. Measuring the effects of stock market liberalization on return volatility is particularly important for policymakers in emerging markets because the latter wish to know the typical benefits and costs associated with their policies so as to make a harmonious arbitrage between financial deregulation and regulation.

In this paper, we firstly developed a bivariate model for measuring emerging market volatility which explicitly allows the world market influences on the volatility of domestic markets. When the conditional volatility indices of sample emerging markets become available, we then perform some stability tests and a pooled time-series analysis to assess the empirical relationship between stock market liberalization and return volatility. From the structural break analysis, we reinforce the empirical findings of Aggarwal and al. (1999) through proving that none of the estimated break dates in the conditional volatility indices are directly linked to the official liberalization dates. As for the cross-market analysis, it shows evidence that the effects of official liberalization on return volatility are, on average, insignificant. In particular, the variance of stock returns is lowered when the participation of the US investors becomes effective and significant on emerging markets, and when emerging markets increase in size.

According to our results and those of the majority of existing studies, it appears that stock market liberalization does not drive up return volatility. From this point of view, such market reform would be the best way for emerging and developing countries to attract foreign investments and for local companies to benefit reduced cost of capital from international diversification activities. Meanwhile, it is also essential to underline that the embankment of market liberalization process needs to be gradual in order to gain investors' confidence and to prevent the adverse impacts of foreign capital flows. 


\section{NOTES}

${ }^{1}$ See, Global Stock Market Factbook, Standard \& Poor's, 2004.

${ }^{2}$ A detailed survey about theoretical features and empirical applications of various GARCH/ARCH models is presented in Bollerslev and al. (1994).

${ }^{3}$ The official date of liberalization, the date of the first Country Fund and ADR introduction as well as the date of structural changes in the US capital flows for sample markets are taken from Bekaert and Harvey (2000). The information variables are used because they might be influenced by stock market and economic developments subjected to changes when emerging markets become more open to foreign capital flows. It is then expected that they grasp information about stock market liberalization. Concerning the control variables, they are introduced in the pooled time-series model in order to isolate the part of volatility changes attributable to other financial and economic reforms in emerging market countries. 


\section{REFERENCES}

Aggarwal, R., C. Inclan, and R. Leal, 1999, "Volatility in Emerging Stock Markets," Journal of Financial and Quantitative Analysis, 34, 33-55.

Andrews, D.W.K., and W. Ploberger, 1994, "Optimal Tests When a Nuisance Parameter is Present only under the Alternative," Econometrica, 62, 1383-1414.

Bai, J., and P. Perron, 1998, "Estimating and Testing Linear Models with Multiple Structural Shanges," Econometrica, 66, 47-78.

Bai, J., and P. Perron, 2003, "Computation and Analysis of Multiple Structural Change Models," Journal of Applied Econometrics, 18, 1-22.

Bekaert, G., and C.R. Harvey, 1995, "Time-varying World Market Integration," Journal of Finance, 50, 403-444.

Bekaert, G., and C.R. Harvey, 1997, "Emerging Equity Market Volatility," Journal of Financial Economics, 43, 29-78.

Bekaert, G. and C.R. Harvey, 2000, "Foreign Speculators and Emerging Equity Markets," Journal of Finance, 55, 565-613.

Bekaert, G., C.R. Harvey, and C. Lundblad, 2001, "Emerging Equity Markets and Economic Growth," Journal of Development Economics, 66, 465-504.

Bollerslev, T., 1986, "Generalized Autoregressive Conditional Heteroscedasticity," Journal of Econometrics, 31, 307-327.

Bollerslev, T., 1990, "Modelling the Coherence in Short-run Nominal Exchange Rates: A Multivariate Generalized ARCH Model," Review of Economics and Statistics, 72, 498-505.

Bollerslev, T., and J. Wooldridge, 1992, "Quasi-maximum Likelihood Estimations and Inferences in Dynamic Models with Time-varying Covariances," Econometric Reviews, 11, 143-172.

Bollerslev, T., R.F. Engle, and J. Wooldridge, 1988, "A Capital Asset Pricing Model with Time-varying Covariances," Journal of Political Economy, 96, 116-131.

Bollerslev, T., R.F. Engle, and D. Nelson, 1994, "ARCH Models," in Engle R.F., and D.L. McFadden (Eds.), Handbook of Econometrics 4, Amsterdam: North-Holland.

Borensztein, E.R., and R.G. Gelos, 2001, "A Panic-prone Pack? The Behavior of Emerging Market Mutual Funds," Working Paper, International Monetary Fund.

Brown, R.L., J. Durbin, and J.M. Evans, 1975, "Techniques for Testing the Constancy of Regression Relationships over Time," Journal of the Royal Statistical Society, B37, 149-163.

Calvo, S., and C. Reinhart, 1996, "Capital Flows to Emerging Markets: Is There Evidence of Contagion Effects?," in Calvo G. and M. Goldstein (Eds.), Private Capital Flows to Emerging Markets, Institute for International Economics.

Carrieri, F., V. Errunza, and K. Hogan, 2003, "Characterizing World Market Integration through Time," Working Paper, McGill University.

DeSantis, G., and S. Imrohoroglu, 1997, "Stock Returns and Volatility in Emerging Financial Markets," Journal of International Money and Finance, 16, 561-579. 
Engle, R.F., 1982, "Autoregressive Conditional Heteroscedasticity with Estimates of the Variance of UK Inflation," Econometrica, 50, 987-1008.

Engle, R.F., and K.F. Kroner, 1993, "Multivariate Simultaneous Generalized ARCH," Working Paper, University of California, San Diego.

Engle, R.F., R.Y. Chou, and K.F. Kroner, 1992, "ARCH Modeling in Finance," Journal of Econometrics, 52, 5-59.

Froot, K.A., P.G.J. O'Connell, and M.S. Seasholes, 2001, "The Portfolio Flows of International Investors," Journal of Financial Economics, 59, 151-194.

Gerard, B., K. Thanyalakpark, and J.A. Batten, 2003, "Are the East Asian Markets Integrated? Evidence from the ICAPM," Journal of Economics and Business, 55, 585-607.

Hansen, B., 1992, "Parameter Instability in Linear Models," Journal of Policy Modeling, 14, 517-533.

He, L.T., 2001, "Time Variation Paths of International Transmission of Stock Volatility - US vs. Hong Kong and South Korea," Global Finance Journal, 12, 19-43.

Henry, P.B., 2000, "Stock Market Liberalization, Economic Reform, and Emerging Market Equity Prices," Journal of Finance, 55, 529-563.

Iwata, S. and S. Wu, 2004, "Stock Market Liberalization and International Risk Sharing," Working Paper, University of Kansas.

Jayasuriya, S., 2005, "Stock Market Liberalization and Volatility in the Presence of Favorable Market Characteristics and Institutions," Emerging Markets Review, 6, 170-191.

Kassimatis, K., 2002, "Financial Liberalization and Stock Market Volatility in Selected Developing Countries," Applied Financial Economics, 12, 389-394.

Khambata, D., 2000, "Impact of Foreign Investment on the Volatility and Growth of Emerging Stock Markets," Multinational Business Review, 8, 50-59.

Kim, E.H., and V. Singal, 2000, "Stock Market Openings: Experience of Emerging Economies," Journal of Business, 73, 25-66.

Krämer, W., W. Ploberger, and R. Alt, 1988, "Testing for Structural Change in Dynamic Models," Econometrica, 56, 1355-1369.

Krugman, P., 1998, "Saving Asia: It's Time to Get Radical," Fortune, Sept. 7, 74-80.

Levine, R., and S. Zervos, 1998, "Capital Market Liberalization and Stock Market Development," World Development, 26, 1169-1183.

Liu, Y.A., and M.S. Pan, 1997, "Mean and Volatility Spillover Effects in the US and Pacific-Basin Stock Markets," Multinational Finance Journal, 1, 47-62.

Miles, W., 2002, "Financial Deregulation and Volatility in Emerging Equity Markets," Journal of Economic Development, 27, 113-126. 
Table 1

Estimation results of the impirical model for emerging market volatility

Panel A - Coefficients in the bivariate conditional mean specification

\begin{tabular}{|c|c|c|c|c|c|c|c|}
\hline Model coefficients & Argentina & Brazil & Chile & Colombia & Malaysia & Mexico & Thailand \\
\hline$\beta_{0}$ & $\begin{array}{c}0,010^{*} \\
(0,004)\end{array}$ & $\begin{array}{c}-0,055 \\
(0,040)\end{array}$ & $\begin{array}{c}0,081 \\
(0,130)\end{array}$ & $\begin{array}{c}-0,003 \\
(0,032)\end{array}$ & $\begin{array}{c}0,007 \\
(0,006)\end{array}$ & $\begin{array}{c}0,049 \\
(0,034)\end{array}$ & $\begin{array}{c}0,014 \\
(0,013)\end{array}$ \\
\hline$\beta_{1}$ & $\begin{array}{c}0,023 \\
(0,092)\end{array}$ & $\begin{array}{c}0,040 \\
(0,049)\end{array}$ & $\begin{array}{l}0,234^{* *} \\
(0,043)\end{array}$ & $\begin{array}{l}0,372^{* *} \\
(0,092)\end{array}$ & $\begin{array}{c}0,154^{*} \\
(0,078)\end{array}$ & $\begin{array}{l}0,188^{* *} \\
(0,060)\end{array}$ & $\begin{array}{l}0,314^{* *} \\
(0,050)\end{array}$ \\
\hline$\beta_{2}$ & $\begin{array}{c}-0,058 \\
(0,220)\end{array}$ & $\begin{array}{c}0,229 \\
(0,189)\end{array}$ & $\begin{array}{c}0,129 \\
(0,125)\end{array}$ & $\begin{array}{l}0,385^{\text {** }} \\
(0,122)\end{array}$ & $\begin{array}{l}-0,122 \\
(0,123)\end{array}$ & $\begin{array}{c}0,229 \\
(0,157)\end{array}$ & $\begin{array}{l}-0,014 \\
(0,161)\end{array}$ \\
\hline $\begin{array}{c}\beta_{3} \\
\text { (Sensitivity to the } \\
\text { global market risk } \\
\text { factor) }\end{array}$ & $\begin{array}{c}0,265 \\
(1,622)\end{array}$ & $\begin{array}{c}-10,273^{* *} \\
(3,235)\end{array}$ & $\begin{array}{c}4,750 \\
12,047)\end{array}$ & $\begin{array}{c}3,098 \\
(3,741)\end{array}$ & $\begin{array}{c}-1,270 \\
(1,289)\end{array}$ & $\begin{array}{c}4,878 \\
(5,174)\end{array}$ & $\begin{array}{l}-1,891 \\
(2,331)\end{array}$ \\
\hline $\begin{array}{l}\beta_{4} \\
\text { (Sensitivity to the lo- } \\
\text { cal market risk fac- } \\
\text { tor) }\end{array}$ & $\begin{array}{l}-0,137 \\
(0,388)\end{array}$ & $\begin{array}{c}3,384^{*} \\
(1,695)\end{array}$ & $\begin{array}{c}-7,551 \\
(14,558)\end{array}$ & $\begin{array}{l}-0,267 \\
(4,459)\end{array}$ & $\begin{array}{c}0,675 \\
(0,969)\end{array}$ & $\begin{array}{l}-3,568 \\
(2,902)\end{array}$ & $\begin{array}{l}-0,899 \\
(1,466)\end{array}$ \\
\hline $\begin{array}{l}\text { Values of the log- } \\
\text { likelihood function }\end{array}$ & 1157.07 & 1293.24 & 1431.87 & 983.98 & 974.03 & 1375.71 & 1445.84 \\
\hline
\end{tabular}

Panel B - Robust tests for model standardized residuals

\begin{tabular}{lccccccc}
\hline & Argentina & Brazil & Chile & Colombia & Malaysia & Mexico & Thailand \\
\hline Mean & 0,086 & $-0,003$ & $-0,003$ & 0,030 & $-0,039$ & $-0,015$ & 0,014 \\
\hline $\begin{array}{l}\text { Standard devia- } \\
\text { tion }\end{array}$ & 0,193 & 0,239 & 0,388 & 0,492 & 0,433 & 0,315 & 0,390 \\
\hline Skewness & $-0,586^{* *}$ & $-0,755^{* *}$ & $-0,672^{* *}$ & $-0,729^{* *}$ & $-0,849^{* *}$ & $-0,766^{* *}$ & $-0,390^{* *}$ \\
\hline Kurtosis & $2,952^{* *}$ & $2,120^{* *}$ & $1,809^{* *}$ & $2,260^{* *}$ & $3,249^{* *}$ & $2,124^{* *}$ & $1,217^{* *}$ \\
\hline Q(12) & 12,947 & 17,585 & 17,292 & 16,896 & 14,054 & 16,164 & 20,134 \\
\hline JB & $131,579^{++}$ & & $68,402^{++}$ & $97,478^{++}$ & $180,959^{++}$ & $92,417^{++}$ & $28,177^{++}$ \\
\hline ARCH(12) & 1,097 & 2,051 & 1,911 & 1,819 & 2,507 & 2,376 & 0,564
\end{tabular}

Notes: Conditional volatility of sample emerging markets is estimated using our bivariate model for stock market volatility. Bollerslev and Wooldridge (1992)'s robust standard errors are given in parentheses. Q-statistics are the Ljung-Box test for serial correlation applied to returns in level up to 12 lags. JB refers to the Jarque and Bera (1980)'s test for normality. ARCH is the Engle (1982)'s test for conditional heteroscedasticity. ${ }^{*}$ and ${ }^{* *}$ indicate significance of coefficients at the $5 \%$ and $1 \%$ respectively. ${ }^{+}$and ${ }^{++}$indicate rejection of the null hypotheses of no autocorrelation, normality and homocedasticity at the $5 \%$ and $1 \%$ levels of significance respectively for statistical tests. 


\section{Table 2}

Results of the Bai-Perron's test for multiple structural breakpoints

\begin{tabular}{|c|c|c|c|}
\hline Market & Number of breakpoints & Estimated break dates & $\begin{array}{l}95 \% \text { confidence intervals for } \\
\text { break dates }\end{array}$ \\
\hline Argentina & 1 & 1989:06 & [1988:02 - 1991:03] \\
\hline Brazil & 3 & $\begin{array}{l}1987: 03 \\
1991: 07 \\
1998: 07 \\
\end{array}$ & $\begin{array}{l}{[1985: 02-1987: 04]} \\
{[1991: 06-1993: 02]} \\
{[1996: 01-1998: 09]}\end{array}$ \\
\hline Chile & 1 & 1992:04 & [1991:07 - 1998:03] \\
\hline Colombia & 2 & $\begin{array}{l}\text { 1992:11 } \\
1997: 08\end{array}$ & $\begin{array}{l}{[1992: 10-1995: 08]} \\
{[1996: 03-1997: 09]}\end{array}$ \\
\hline Malaysia & 2 & $\begin{array}{l}\text { 1997:06 } \\
\text { 2000:02 }\end{array}$ & $\begin{array}{l}{[1996: 07-1997: 07]} \\
{[2000: 01-2001: 02]}\end{array}$ \\
\hline Mexico & 2 & $\begin{array}{l}\text { 1982:07 } \\
\text { 1991:07 }\end{array}$ & $\begin{array}{l}{[1979: 07-1982: 10]} \\
{[1990: 08-1996: 03]}\end{array}$ \\
\hline Thailand & 1 & 1997:08 & [1996:01 - 1997:09] \\
\hline
\end{tabular}

Notes: The breakpoint selection procedure in the works of Bai and Perron $(1998,2003)$ is based on the Bayesian Information Criteria (BIC). First, we arbitrarily set the maximum number of breaks to be 5 . If the effective number of breaks is equal to 5, a higher number of breaks will be chosen so that the testing procedure captures all possible breakpoints. In principle, a model's optimal number of breakpoints is the one associated with the minimum BIC. For the countries considered in this present study, none of the volatility series has more than 5 breakpoints. 


\section{Table 3}

Stock market liberalization dates

\begin{tabular}{|l|c|c|c|c|}
\hline Market & $\begin{array}{c}\text { Official dates of } \\
\text { liberalization }\end{array}$ & $\begin{array}{c}\text { Date of the first } \\
\text { ADR introduction }\end{array}$ & $\begin{array}{c}\text { Date of the first Coun- } \\
\text { try Fund introduction }\end{array}$ & $\begin{array}{c}\text { Date of the structural } \\
\text { break in the US capital } \\
\text { flows }\end{array}$ \\
\hline Argentina & $11-1989$ & $08-1991$ & $10-1991$ & $04-1993$ \\
Brazil & $05-1991$ & $01-1992$ & $10-1987$ & $06-1986$ \\
Chile & $01-1992$ & $03-1990$ & $09-1989$ & $01-1988$ \\
Colombia & $02-1991$ & $12-1992$ & $05-1992$ & $08-1993$ \\
Malaysia & $12-1988$ & $08-1992$ & $12-1987$ & $04-1992$ \\
Mexico & $05-1989$ & $01-1989$ & $06-1981$ & $05-1990$ \\
Thailand & $09-1987$ & $01-1991$ & $07-1985$ & $07-1988$ \\
\hline
\end{tabular}

Notes: all the dates reported in this table are derived from Bekaert and Harvey (2000) 
Table 4

Effects of stock market liberalization on volatility

Pooled OLS Estimation

Dependent Variable: VOLATILITY

Number of cross-sections used: 7

White Heteroscedasticity-Consistent Standard Errors \& Covariance

\begin{tabular}{|c|c|c|c|}
\hline Dependent variables & Regression 1 & Regression 2 & Regression 3 \\
\hline VOLATILITY $_{\mathrm{t}-1}$ & $\begin{array}{l}0.501^{* *} \\
(0.116)\end{array}$ & $\begin{array}{l}0.500^{* *} \\
(0.118)\end{array}$ & $\begin{array}{l}0.521^{* *} \\
(0.113)\end{array}$ \\
\hline OPENING & $\begin{array}{c}-0.009 \\
(0.012)\end{array}$ & $\begin{array}{l}-0.010 \\
(0.012)\end{array}$ & $\begin{array}{l}-0.008 \\
(0.012)\end{array}$ \\
\hline $\mathrm{CF}$ & $\begin{array}{l}-0.024 \\
(0.022) \\
\end{array}$ & $\begin{array}{c}-0.026 \\
(0.022) \\
\end{array}$ & $\begin{array}{c}-0.024 \\
(0.023)\end{array}$ \\
\hline ADR & $\begin{array}{c}0.000 \\
(0.002)\end{array}$ & $\begin{array}{c}0.000 \\
(0.002)\end{array}$ & $\begin{array}{c}0.000 \\
(0.002)\end{array}$ \\
\hline USCF & $\begin{array}{l}-0.008^{c} \\
(0.004)\end{array}$ & $\begin{array}{l}-0.010^{*} \\
(0.005)\end{array}$ & $\begin{array}{l}-0.012^{*} \\
(0.004)\end{array}$ \\
\hline MCAP/GDP $(\times 10)$ & & $\begin{array}{c}-0.006^{* *} \\
(0.001)\end{array}$ & $\begin{array}{c}-0.004^{* *} \\
(0.001)\end{array}$ \\
\hline TRADE/GDP & & $\begin{array}{c}0.012^{*} \\
(0.005)\end{array}$ & $\begin{array}{c}0.010^{*} \\
(0.004)\end{array}$ \\
\hline TURNOVER & & $\begin{array}{l}0.082^{* *} \\
(0.041)\end{array}$ & $\begin{array}{l}0.097^{* *} \\
(0.037)\end{array}$ \\
\hline INF & & & $\begin{array}{l}-0.168^{* *} \\
(0.037)\end{array}$ \\
\hline INT & & & $\begin{array}{l}-0.011^{* *} \\
(0.002)\end{array}$ \\
\hline $\mathrm{EXC}$ & & & $\begin{array}{l}0.107^{* *} \\
(0.015)\end{array}$ \\
\hline PSI & & & $\begin{array}{c}0.041 \\
(0.043)\end{array}$ \\
\hline \multicolumn{4}{|l|}{ Fixed effects } \\
\hline Argentina-C & 0.033 & 0.030 & 0.023 \\
\hline Brazil-C & 0.019 & 0.015 & 0.004 \\
\hline Chile-C & 0.006 & 0.004 & 0.004 \\
\hline Colombia-C & 0.004 & 0.001 & 0.001 \\
\hline Malaysia-C & 0.007 & -0.004 & -0.003 \\
\hline Mexico-C & 0.010 & 0.003 & 0.002 \\
\hline Thailand-C & 0.009 & -0.002 & -0.002 \\
\hline Number of Observations & 1190 & 1164 & 1164 \\
\hline Adjusted R-squared & 0.419 & 0.424 & 0.617 \\
\hline
\end{tabular}

Notes:

This table reports estimated coefficients from the pooled OLS estimation of the regression model in (5). Standard errors which are robust to general heteroscedasticity are given in parentheses. The estimation period is arbitrarily chosen to be from January 1986 to March 2000 in order to avoid the impact of undesired factors.

and ${ }^{* *}$ indicate significance at the $5 \%$ and $1 \%$ respectively.

${ }^{\mathrm{c}}$ indicates significance at the $10 \%$ level of significance. 
Figure 1

Volatility dynamics in Latin American markets

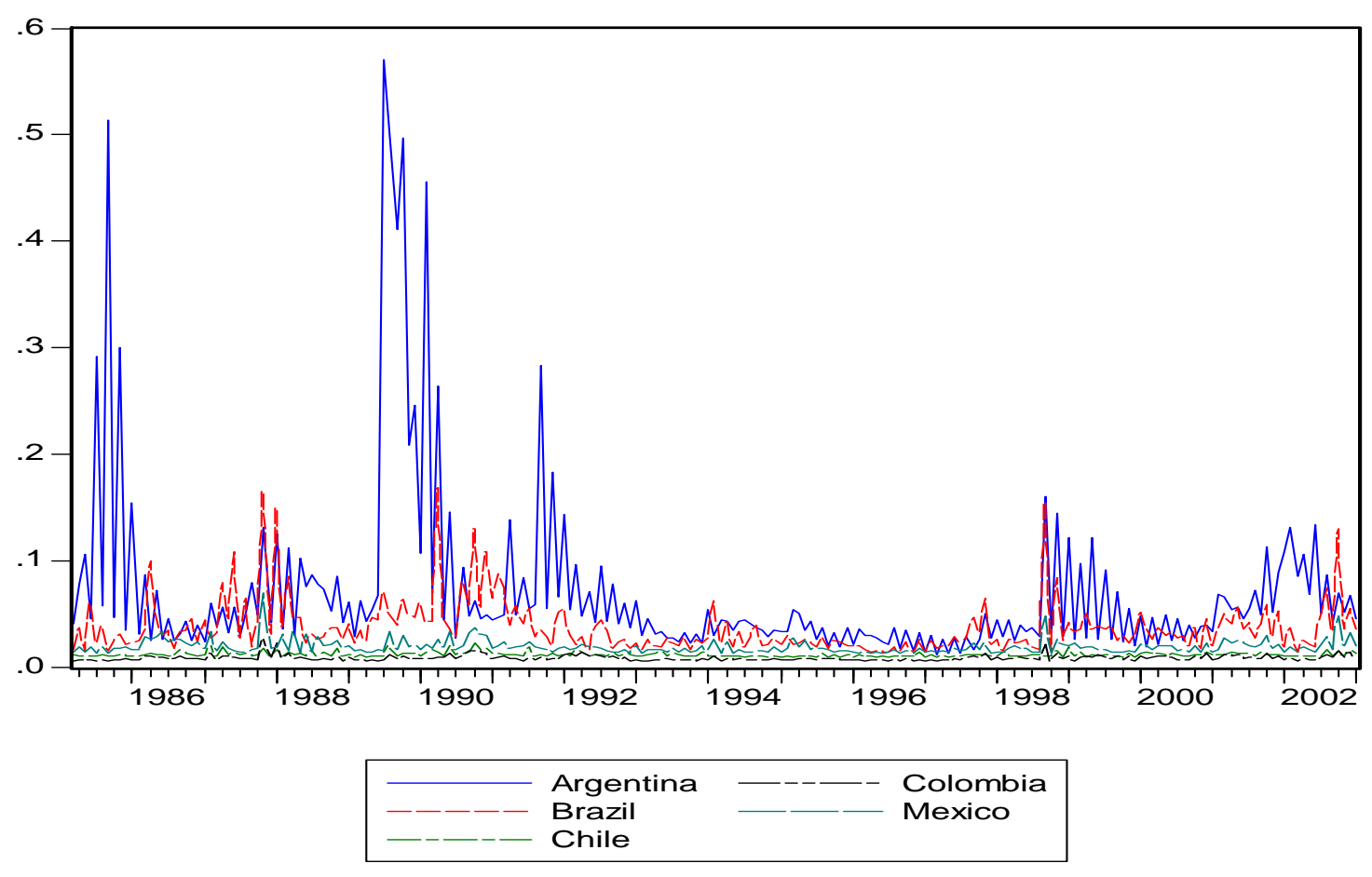


Figure 2

Volatility dynamics in Asian markets

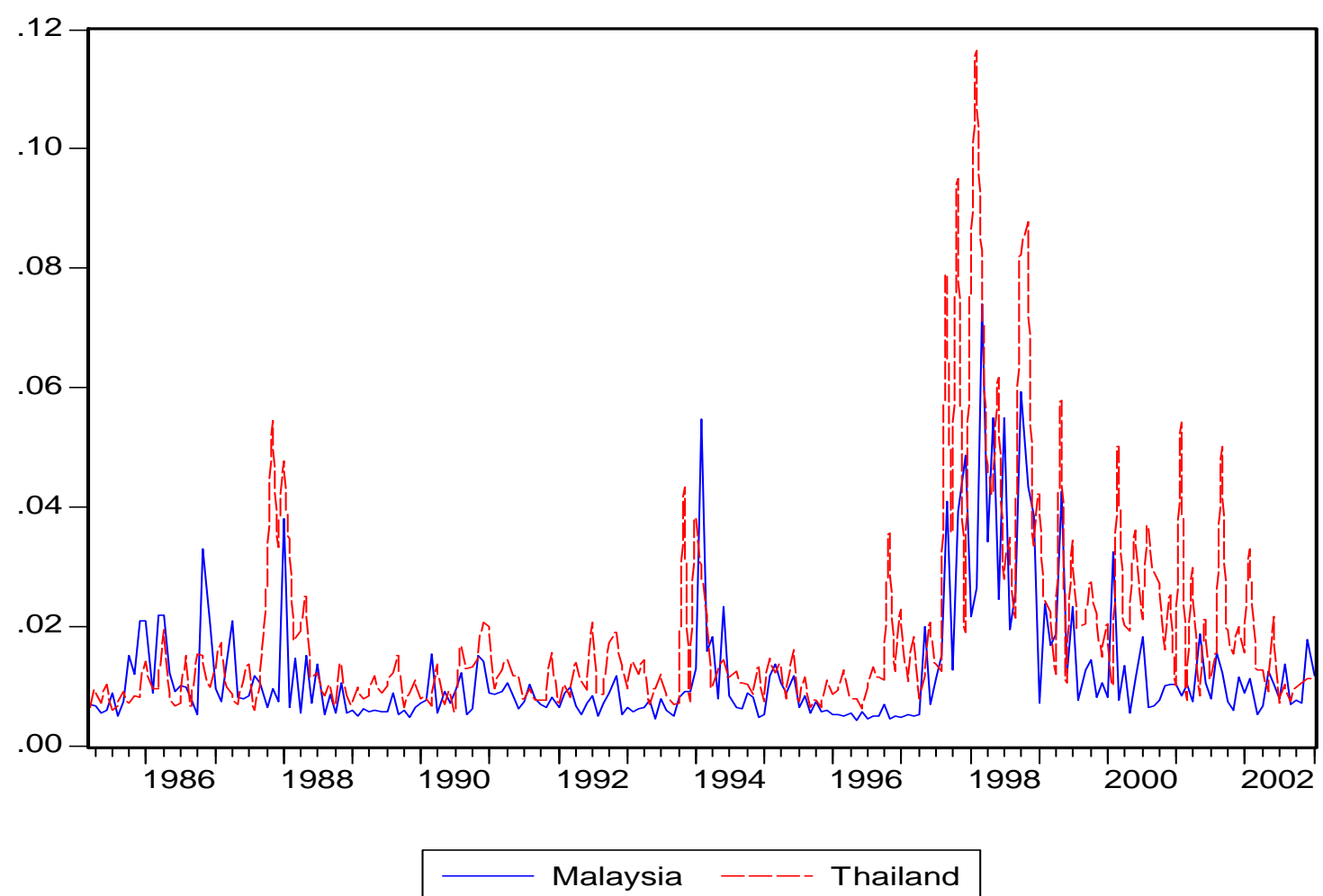




\section{Figure 3}

CUSUM path for the conditional volatility indices

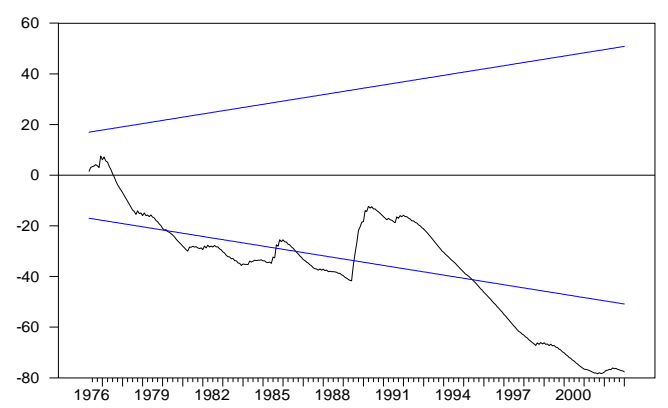

Argentina

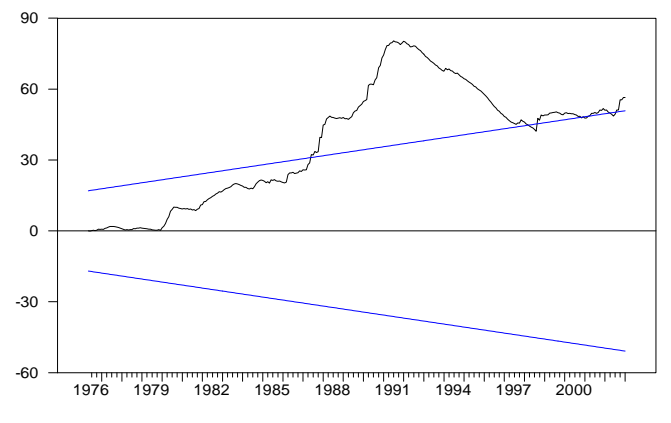

Brazil

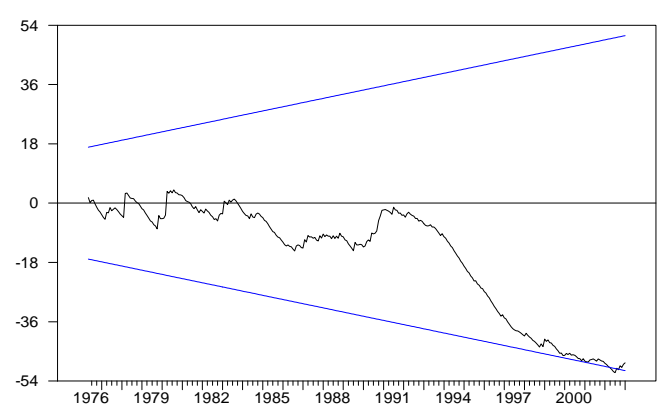

Chile

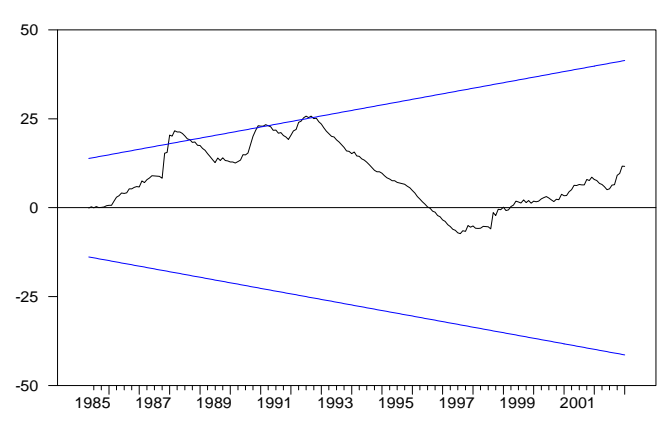

Colombia
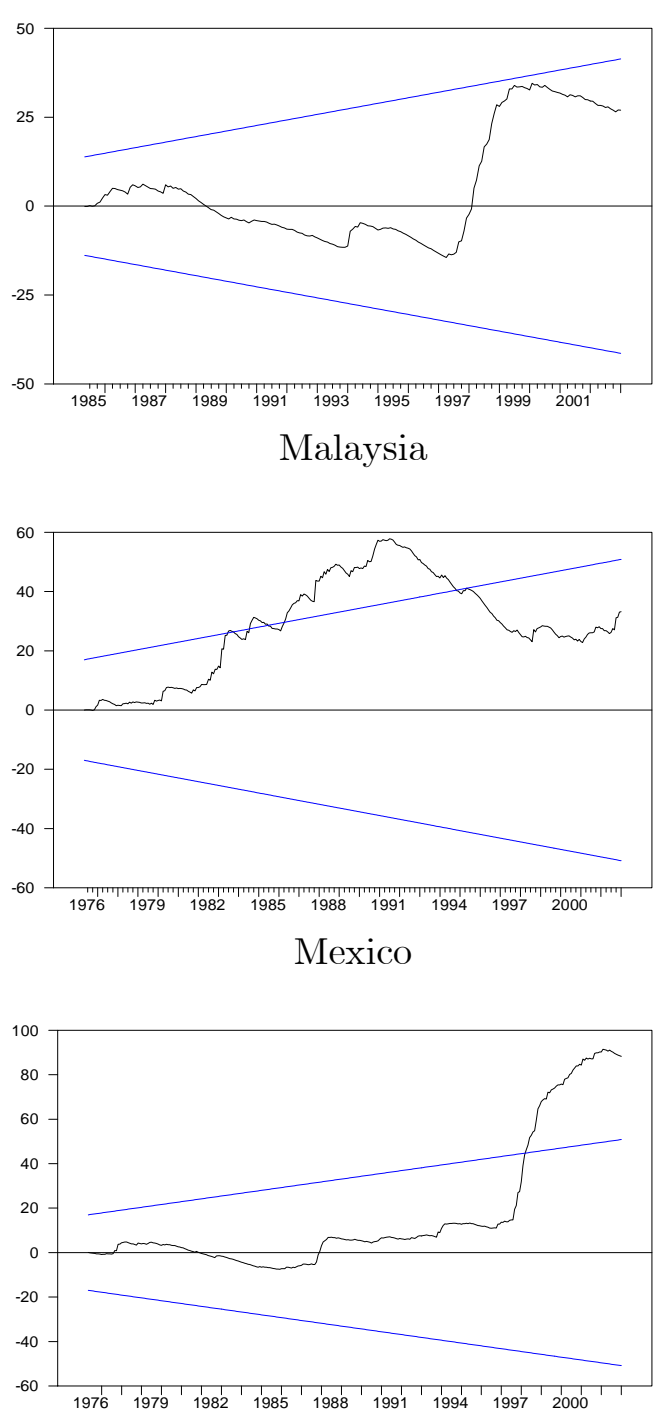

Thailand 


\section{Figure 4}

BIC and residual sum of squares (RSS) for models with $m$ breakpoints

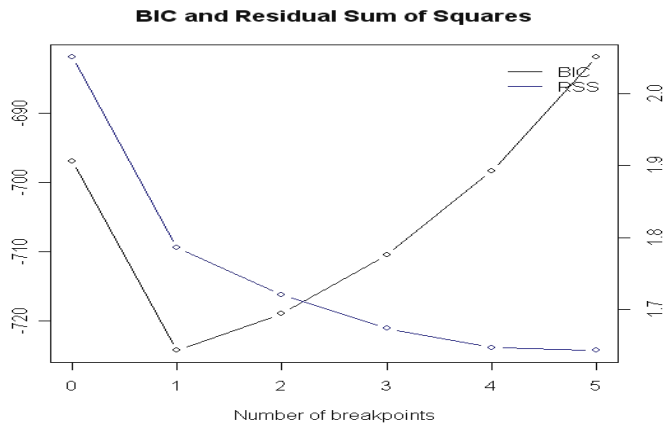

Argentina
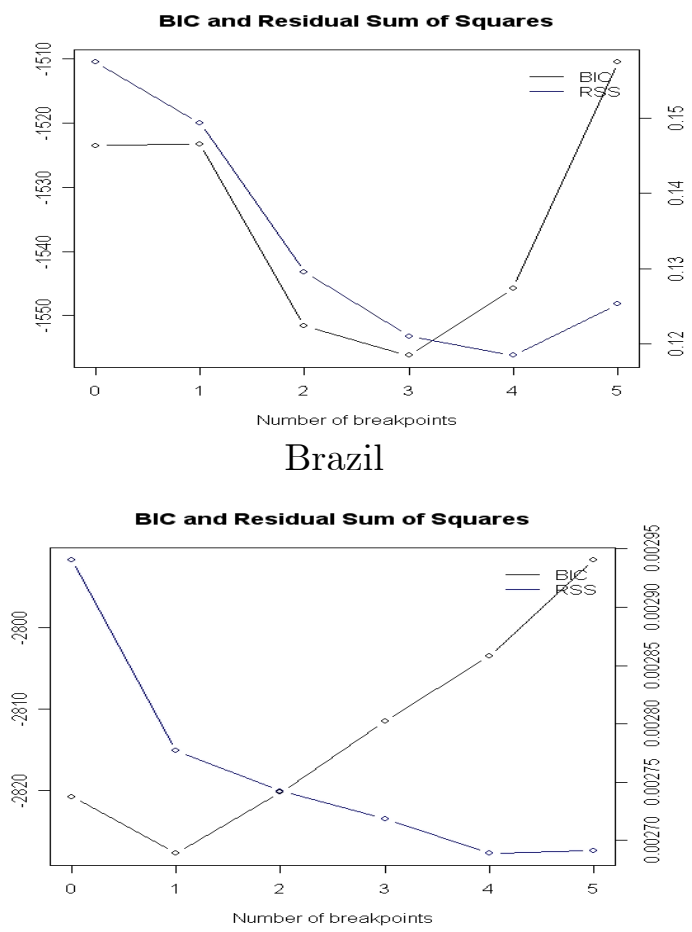

Chile

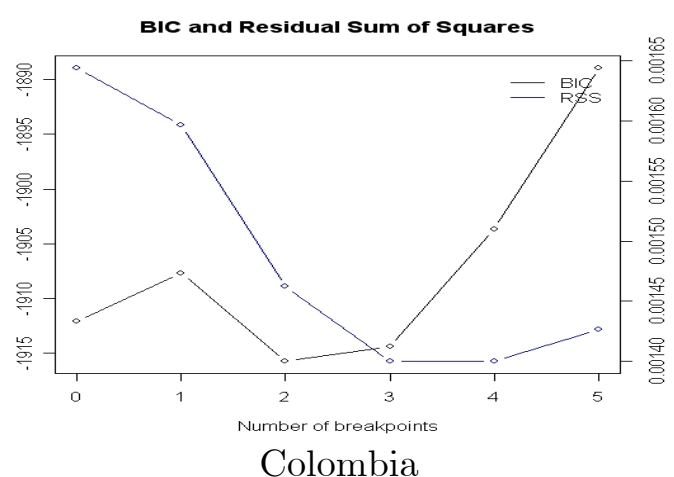

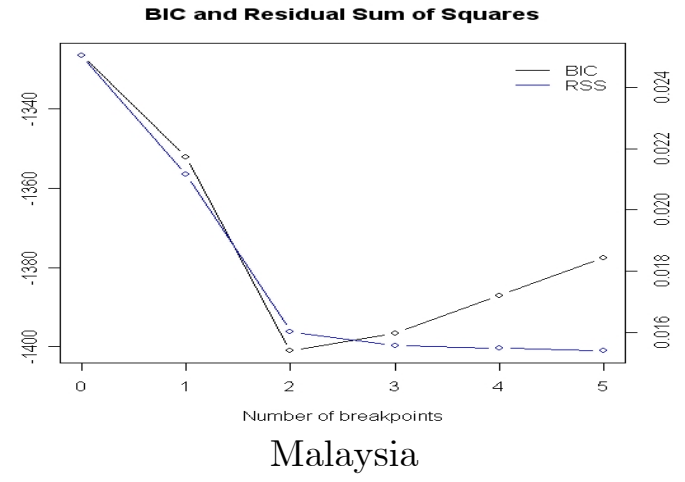

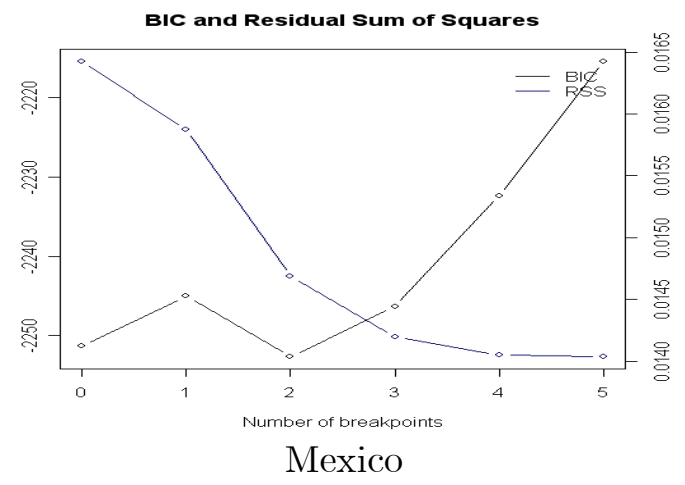

BIC and Residual Sum of Squares

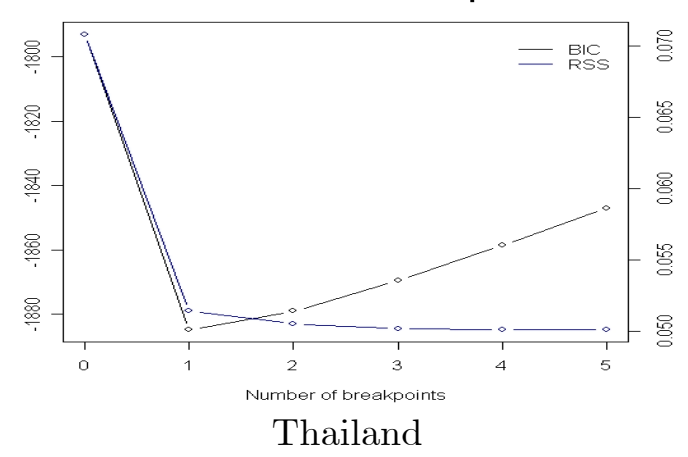

